\title{
Novas Conjunturas Industriais e Participação Local em Estratégias de Desenvolvimento*
}

\author{
José Ricardo Ramalho
}

$\mathrm{E}$ mpresas integrantes de cadeias produtivas globais, ao se instalarem em novas localidades e regiões, produzem dinâmicas criadoras de situações que tendem a alterar as condições de desenvolvimento econômico e os padrões de participação institucional e política. A proposta do texto é discutir as questões relacionadas à formação desses novos padrões de participação, atribuindo relevância à ação de redes sociopolíticas que se constituem nas localidades onde ocorrem as atividades industriais. A situação analisada é conseqüência da dinâmica do setor automobilístico brasileiro, que ao longo dos anos de 1990 passou por um processo de reestruturação, fazendo novos investimentos e construindo novas fábricas e afetando antigas e novas regiões industrializadas.

Pretende-se argumentar, a partir de um caso regional de implantação recente de unidades fabris da indústria automotiva (Sul Fluminense),

\footnotetext{
* Este texto foi escrito sob os auspícios do Bellagio Study Center - The Rockefeller Foundation, que me acolheu, na qualidade de pesquisador-visitante, em Bellagio, na Itália, oferecendo-me durante um mês, no ano de 2004, condições ideais de trabalho. Os dados, informações e entrevistas que sustentam o texto são resultados parciais de projetos de pesquisa apoiados pelo Conselho Nacional de Desenvolvimento Científico e Tecnológico - CNPq e pela Fundação de Amparo à Pesquisa do Estado do Rio de Janeiro - FAPERJ (Programa Cientistas do Nosso Estado), instituições às quais também sou grato. Finalmente devo mencionar e agradecer a leitura atenta e crítica de Neide Esterci e dos pareceristas anônimos de Dados.
}

DADOS - Revista de Ciências Sociais, Rio de Janeiro, Vol. 48, n³ 3, 2005, pp. 491 a 524. 
que, mesmo em um contexto em que a introdução inicial de grandes empresas tem motivações oportunistas - isenções fiscais, empréstimos públicos generosos, baixos salários etc. - , sem nenhuma perspectiva de cooperação com as instituições econômicas e políticas locais, podem emergir iniciativas de mobilização e intervenção da sociedade no sentido de interferir na política industrial e fomentar atividades de colaboração visando ao desenvolvimento da região.

O aglomerado industrial da hipótese aqui examinada foi instalado sob a forma de "produção enxuta", o que não autorizaria a crer na sua capacidade de gerar situações que levem a formulação de estratégias de integração das empresas entre si, e entre elas e o poder público e a sociedade civil. Na ausência de uma ação do tipo que levou aos efeitos de desenvolvimento observados nos "distritos industriais italianos", que se baseiam na articulação "virtuosa" entre pequenas empresas para a formação de arranjos cooperativos, será que é possível pensar que, em situações de aglomeração industrial como as do Sul Fluminense, possa haver elementos da sociedade civil, acúmulos históricos, capital social capaz de provocar efeitos ao menos semelhantes? Diante de uma indústria que cada vez mais reduz os seus custos de produção, entre outras coisas, graças ao rebaixamento de salários e ao corte de postos de trabalho, perante a explicitação por parte das indústrias de que o deslocamento espacial visa a auferir ainda mais ganhos seja às expensas dos trabalhadores ou do Estado, será que vale a pena perguntar sobre os eventuais efeitos positivos para a sociedade como um todo e especialmente para os trabalhadores da região, que a presença dessas indústrias possa provocar?

Por razões que serão demonstradas mais adiante, no caso estudado, a presença dessas empresas tem de fato funcionado como um indutor da necessidade de cooperação para o desenvolvimento econômico. Isso pressupõe aceitar que os atores políticos das localidades da região possam se capacitar para atuar - até mesmo para contestar - na gestão da nova fase do desenvolvimento local. De forma diferenciada, também pode operar no sentido de moldar o desenvolvimento a favor dos interesses econômicos e sociais da sociedade local. Neste coletivo estariam incluídos os trabalhadores, principalmente aqueles contratados pelas novas empresas, que além de constituírem um grupo social expressivo, com novas expectativas e demandas no espaço da fábrica e da cidade, transformariam a organização sindical em participante potencialmente relevante nesse processo. 


\section{A ARGUMENTAÇÃO TEÓRICA}

Tratar desta temática implica em dialogar com um conjunto de questões teóricas, presente na literatura das ciências sociais e econômicas, a começar pela análise dos desdobramentos da crise da produção fordista, que resultou na reestruturação das grandes empresas verticalizadas e rígidas, transformadas em organizações mais flexíveis e articuladas em redes, formando cadeias produtivas globais ${ }^{1}$, afetando as relações de trabalho e as localidades onde estão instaladas. A facilidade com que as fábricas "enxutas" conseguem se deslocar de um espaço geográfico para outro teria significado, por um lado, o aumento do poder discricionário das empresas, sempre em busca de lugares com mão-de-obra barata e grandes incentivos fiscais, como acontece com os países tardiamente industrializados; por outro lado, teria feito crescer a importância econômica e política dos locais onde estão instaladas as empresas reestruturadas, a partir do momento em que esses locais ${ }^{2}$ passaram a fazer parte de um circuito global. Esta situação, identificada em vários países, incluindo o Brasil, poderia ser entendida como capaz de mexer com estratégias empresariais globais e nacionais e com políticas de desenvolvimento econômico e social locais, regionais e nacionais. Nessa "nova ordem econômica regional", os sistemas econômicos regionais modernos poderiam ser vistos não apenas como representados por um domínio puramente privado, no qual prevalecem as relações mercadológicas, mas também como um "domínio coletivo de exterioridades, que é a nascente de vantagens competitivas e efeitos de desenvolvimento, mas que deve ser gerenciado por instituições públicas adequadas, a fim de garantir a totalidade dos benefícios que gera" (Scott, 1999:30-31).

A discussão sobre estratégias de desenvolvimento local associada a esse novo momento da indústria automobilística brasileira - de descentralização e deslocamento para fora das regiões metropolitanas tem incorporado formulações sobre dinâmicas que valorizam "não apenas as relações econômicas produtivas, mas também a eficácia das relações não mercantis entre os homens" (Pires, 2004:3). Segundo este autor, essas dinâmicas ultrapassariam "a valorização dos mercados de bens materiais de consumo, agora envolvendo os serviços, as tradições e os saberes locais, transformados em recursos que dão suporte a várias atividades econômicas" e constituiriam elementos estratégicos das ações dos atores sociais locais (ibidem). Do mesmo modo, nessa perspectiva se valorizam cada vez mais as cidades e não apenas as em- 
presas como contextos dos processos de desenvolvimento local. Cocco et alii (1999:23-24), por exemplo, chegam a dizer que "a transferência do 'lugar' da produção para os territórios das cidades extrapola a localização estritamente privada característica do regime de acumulação fordista". E que "o espaço da produção, ao deixar a fábrica e passar a se referenciar na cidade (no território), ganha uma conotação pública inexistente anteriormente".

Considerando que em realidades concretas essas características podem aparecer juntas e muitas vezes em conflito, incorporar a dimensão política na discussão sobre o desenvolvimento local, para explicar o caso em questão, torna-se essencial. A unidade básica de análise seria os atores econômicos locais e as redes sociopolíticas formadas por eles, os quais conformariam um padrão particular de desenvolvimento entre as quais estão empresas e sindicatos. Locke, por exemplo, descrevendo a experiência italiana, considera que

"[...] essas redes criam misturas de recursos e constrangimentos que moldam as escolhas estratégicas para os atores locais. [...] Não apenas estruturam o fluxo de informações e relações entre as entidades econômicas locais, como também oferecem aos atores locais diferentes ligações ou canais de representação nos grupos nacionais de interesse e criadores de políticas." (1995:12)

E sugere que "estratégias bem-sucedidas são construídas sobre redes de associativismo densas mas igualitárias, organização de grupos de interesse e instituições locais que facilitam a troca de informações e a obtenção de recursos escassos, mediam conflitos e geram confiança entre os atores econômicos". A questão decorrente dessa perspectiva é perceber, segundo Roese (2003:40), “como estes vínculos (extra-econômicos) podem ser criados onde eles não foram desenvolvidos historicamente".

Esse contexto estimula o debate sobre os mecanismos de coordenação que resultam no sucesso dos arranjos produtivos. Conforme Roese (ibidem), a questão central passa a ser "a governança, ou seja, como instituições, formais ou não, contribuem para que a política industrial e as estratégias individuais e coletivas das empresas, dos centros de pesquisa, ensino e treinamento, convirjam no sentido de obter (uma) desejada eficiência coletiva". Para Guimarães e Martin (2001:16), o desafio está em saber "como padrões de governança e arranjos típicos que surgem com a chamada produção 'flexível' ou 'enxuta' [...] dão lugar a no- 
vas formas de alocação de bens - materiais e simbólicos - produzidos a partir da atividade econômica", recuperando na análise das experiências de "governança" "a idéia de que a natureza do desenvolvimento econômico é um fenômeno sujeito à contestação política e econômica" (Roese, 2003:21).

As formulações atuais sobre "distritos industriais" são também uma boa referência para se discutir a experiência brasileira em geral e o caso do Sul Fluminense em particular. Markusen (1996:294) traz uma importante contribuição nesse sentido ao elaborar uma tipologia na qual destaca os critérios que tornam as localidades ou as regiões atraentes para a concentração de atividades industriais, e que acima de tudo tornam duradouras essas experiências. E, ao descrever a diversidade de situações que podem manter a atratividade de um local ou de uma região, a autora amplia a discussão sobre os "novos distritos industriais" para além do exemplo dos distritos industriais italianos - apoiados na especialização flexível e na atratividade ligada ao papel da pequena empresa, articulada em um sistema cooperativo regional de governança industrial -, ao incorporar entre outros tipos de distrito industrial diferentes formatos não necessariamente apoiados apenas em pequenas empresas, mas também em relações entre grandes e pequenas empresas.

De fato, o caso do Sul Fluminense não se enquadra no padrão clássico do distrito industrial italiano ${ }^{3}$. No entanto, a região e o município escolhidos para a atividade industrial preponderante apresentam características próximas a de dois tipos descritos por Markusen: o distrito industrial "hub-and-spoke", que é "dominado por uma ou várias grandes firmas, integradas verticalmente em um ou mais setores, circundadas por fornecedores menores e com menos poder" - nesse caso, as empresas ou instituições principais "não são enraizadas localmente, tendo importantes laços com os fornecedores, competidores e consumidores estabelecidos fora do distrito"; e o segundo tipo, chamado de "plataformas satélites", quando as empresas

“[...] são colocadas pelos governos nacionais ou governos regionais a uma certa distância de grandes áreas urbanas como uma forma de estimular desenvolvimento regional e simultaneamente baixar o custo do negócio para firmas competitivas pressionadas pelos altos salários urbanos, aluguéis e impostos". (idem:302) 


\section{DESLOCAMENTOS DA INDÚSTRIA AUTOMOTIVA BRASILEIRA: 0 CASO DO SUL FLUMINENSE}

A indústria automotiva, decisiva para o desenvolvimento do país a partir dos anos 1950, reestruturou sua organização produtiva nos anos 1990, como reflexo da crise de produtividade no âmbito internacional e de um longo período de recessão econômica no mercado interno, associado ao abandono da política de substituição de importações (Abreu et alii, 2000).

Nessa conjuntura, o Brasil tornou-se um importante alvo dos investimentos diretos de empresas multinacionais do setor e, graças aos incentivos fiscais de um "novo regime automotivo" ${ }^{4}$, esses investimentos se traduziram na construção de novas fábricas e na reestruturação das antigas com um dispêndio de mais de US $\$ 20$ bilhões. Ocorreu também um processo de reespacialização da indústria ${ }^{5}$, com um deslocamento para outras regiões e municípios afastados das áreas industriais mais tradicionais, como o $\mathrm{ABC}$ paulista, a maioria sem relação prévia com essa atividade industrial, estimulando uma competição pelas montadoras ${ }^{6}$, e criando novas experiências e novos padrões de desenvolvimento local ${ }^{7}$.

A vinda das fábricas da Volkswagen Ônibus e Caminhões (1996) ${ }^{8}$ - doravante VW - e da PSA Peugeot Citroën (2001) para os municípios vizinhos de Resende e Porto Real, no Vale do Rio Paraíba do Sul, foi resultado dessa política de incentivos fiscais. Em Resende e Porto Real, os primeiros efeitos dos investimentos têm indicado um certo dinamismo das economias locais, com resultados palpáveis em termos do aumento dos recursos públicos, instalação de outras novas empresas, criação de postos de trabalho e novas atividades de serviços ${ }^{9}$.

Os municípios de Resende e Porto Real fazem parte da região fluminense do Médio Paraíba, e estão estrategicamente localizados no meio do principal corredor industrial brasileiro, ao longo da rodovia Rio-São Paulo, sendo próximos de uma das principais empresas siderúrgicas do país, a Companhia Siderúrgica Nacional-doravante CSN, estabelecida em Volta Redonda (RJ), a partir dos anos 1940. Pode-se dizer que foi após a inauguração da CSN que toda essa região, tradicionalmente associada a grandes fazendas de café, começou a mudar o seu perfil de modo a ser hoje anunciada, a partir da vinda da indústria automotiva nos anos 1990, como um pólo de desenvolvimento com "vocação para a indústria metal-mecânica". 
A história industrial de Resende (incluindo Porto Real e Itatiaia - distritos recentemente emancipados), desde os anos 1950, divide-se em diversos ciclos econômicos e sempre esteve associada a grandes firmas, algumas delas ainda presentes no local - indústria química e farmacêutica, de bebidas, energia nuclear, metalurgia e pneus -, mas não é uma história que chame a atenção pela colaboração entre empresas ou por uma forte ligação com a localidade. A predominância de uma cultura da grande empresa descolada da realidade local parece ter sido um traço característico dos ciclos de desenvolvimento industrial anteriores ${ }^{10}$. No caso da indústria automobilística, embora a tendência inicial tenha sido pela manutenção dessa prática, a dinâmica criada pela instalação das empresas e a expectativa estabelecida pela possibilidade de um novo ciclo de crescimento econômico nos municípios, na região e no Estado, parecem indicar uma dinâmica diferente das outras épocas.

Dentre os vários fatores que possibilitaram a escolha de Resende para esse novo tipo de investimento, está o fato de o município enquadrar-se na opção estratégica das empresas de permanecerem geograficamente perto do principal mercado consumidor brasileiro e acessível ao mercado sul-americano. Além da chancela política do governo federal que permitiu ao governo do Estado do Rio de Janeiro participar do "leilão" que se instituiu com o objetivo de atrair as montadoras e suas fornecedoras, enfatizou-se também a vinda das grandes montadoras como promotoras do desenvolvimento econômico ${ }^{11}$. Segundo o ex-secretário de Indústria e Comércio do Estado do Rio de Janeiro, Márcio Fortes, em entrevista concedida a mim, em 7 de maio de 1999,

“Não há país desenvolvido decente no mundo que não tenha uma fábrica de automóveis. [...] A indústria automobilística é uma marca de desenvolvimento industrial. [...] País que se preza tem que ter indústria automobilística. Mais ainda, Estado que se preza no Brasil tem que ter indústria automobilística".

No front municipal, todo esse processo serviu também para rearranjar forças políticas e econômicas locais. O fato mais importante que marcou esse período foi a disputa territorial desencadeada pelo anúncio da vinda da VW, e que resultou concretamente na emancipação do município de Porto Real, em 1995. Nesse contexto, a localização da fábrica foi moeda de troca, tendo sua permanência em Resende sido condicionada a um plebiscito sobre a emancipação. Em seguida, Porto Real foi escolhido para ser a base municipal da PSA Peugeot Citroën e de seus 
fornecedores, e da Galvasud - empresa siderúrgica resultado de uma parceria entre a ThyssenKrupp e a CSN -, cuja produção é voltada para a indústria automobilística.

Uma relação direta também se fez entre a doação de terrenos privados para a instalação das empresas e a negociação política da emancipação. Os terrenos pertenciam a um dos principais empresários locais, dono do Grupo Porto Real, que entre outras empresas controlava mais notadamente a Coca-Cola regional, além de ser proprietário de uma grande quantidade de terras oriundas de antigo canavial. Como aponta Bernardelli,

\begin{abstract}
“A Volkswagen [anunciou] que a empresa ficaria em Resende, [...] numa fazenda chamada Piquet, no distrito de Porto Real. Aí houve uma comoção na cidade de Resende. [...] Porque foi uma doação de 2 milhões de metros quadrados do Grupo Porto Real que veio sensibilizar e conseguir que esse grande parque industrial da Volkswagen Ônibus e Caminhões [...] ficasse em Porto Real, porque a fazenda era propriedade desse grupo que cedeu parte do seu patrimônio para a Volkswagen se instalar. [...] O atual prefeito de Resende [...] era, na época, deputado estadual [...] e começou a dizer: 'não, nós não queremos que a Volkswagen vá para Porto Real'. E [...] começou a fazer 'lobby' na assembléia para que os deputados não aprovassem esse projeto. [...] Aí, nós resolvemos dizer: está bem, vocês querem a Volkswagen? Mas nós queremos a nossa independência [...]" (S. Bernardelli, prefeito de Porto Real, 2003).
\end{abstract}

Nesse caso parece ter prevalecido a estratégia da competição, tradicional entre os municípios brasileiros. No entanto, embora a nova aglomeração industrial tenha sido formada a partir de uma política predatória de incentivos fiscais, já há indícios de que as instituições municipais e estaduais voltadas para o desenvolvimento econômico têm atuado no sentido da criação de um novo pólo industrial "metal-mecânico". São várias iniciativas em termos de legislação e criação de novos mecanismos de incentivo ao investimento na região, orientadas pela preocupação com o crescimento econômico e a geração de empregos. A situação parece ter evoluído, graças à sinergia proporcionada pelas atividades da indústria automotiva e pela possibilidade de um novo ciclo de prosperidade, embora em condições diferentes de fases anteriores. Articula-se um movimento no sentido de criar mecanismos indutores da formação de coletivos com interesses comuns ${ }^{12}$. 
O exemplo descrito pelo secretário municipal de indústria e comércio de Resende parece significar um avanço na direção de uma discussão intermunicipal:

\begin{abstract}
"Existe um fórum de secretários, principalmente com a nossa secretaria de desenvolvimento econômico. Você não vê muita reunião, mas existe o fórum de secretários de indústria e comércio. Até porque a gente tem que falar a mesma linguagem. [...] Quando a empresa vem procurar a região, a gente quer que ela se instale aqui, pode ser Itatiaia, Quatis ou Porto Real" (Antonio Gastão, secretário de Indústria, Comércio e Turismo de Resende, 2001).
\end{abstract}

Independentemente da motivação das grandes empresas, a situação criada pela sua instalação acabou tendo o efeito de empurrar as entidades empresariais regionais e locais na direção de novas iniciativas de integração entre empresas, estimulando as de pequeno e médio porte, principalmente no setor de serviços, a se habilitarem no fornecimento as grandes. A Federação das Indústrias do Estado do Rio de Janeiro doravante Firjan - regional tem de certa forma liderado esse processo de discussão. A implantação e as reuniões regulares da Comissão Intermunicipal de Resende, Itatiaia, Porto Real e Quatis, com a presença constante de representantes de empresas de todos os tipos - industriais, agrícolas e de serviços -, de secretários e de prefeitos, revela um importante fórum criado com o objetivo de debater as questões locais. Percebe-se, no entanto, uma pequena ou quase nenhuma participação de trabalhadores ou sindicatos nessas iniciativas. $\mathrm{O}$ acesso às atas das reuniões da Comissão permitiu identificar práticas associadas diretamente à nova realidade econômica desencadeada pelas montadoras. Segundo Henrique Nora,

“A Firjan [...] precisa estar presente nas diversas discussões não só voltadas exclusivamente para o setor industrial, [...] mas discutindo todas as demandas da sociedade. [...] Nós implantamos as comissões intermunicipais [...], e essas comissões têm plena liberdade de atuar em nome da Firjan dentro dos limites desses municípios. [...] São sempre articuladas, dirigidas e presididas por um membro do conselho e se reúnem mensalmente. [...] Nós temos um acompanhamento de tudo o que acontece não só diretamente ligado à atividade industrial, mas também às demandas da sociedade, enfim, porque são chamados a participar dessa discussão não só empresários, mas também os outros setores da sociedade, o poder público" (Henrique Nora, diretor regional da Firjan, 2002). 
Uma parte das discussões tem se voltado para os impactos da vinda da indústria automobilística, inclusive para o mercado de trabalho local, mas também tem significado um entendimento com as prefeituras da região. Nora questiona

\begin{abstract}
"(O que se discute nessas comissões?) [...] Geralmente problemas que afetam o trabalho das indústrias e questões da sociedade local. (Mercado de trabalho também?) Mercado de trabalho.[...] O nosso braço de formação profissional está sempre presente, o Senai. [...] Lá na fábrica da Peugeot Citroën nós formamos praticamente toda mão-de-obra aqui dentro do Senai. [...] Temos parceria com todas as prefeituras. São nossos parceiros e temos com eles uma perfeita integração. Lógico que com uns prefeitos mais, com outros menos, mas de um modo geral [...] (E tem resultado em políticas concretas?) Temos o fórum de logística e desenvolvimento do sul do estado. Temos discutido a implantação, o desenvolvimento organizado da região porque a gente vê que o desenvolvimento passa por aqui, mas que ele precisa se fazer de forma organizada" (Henrique Nora, 2002).
\end{abstract}

A questão da educação, formação técnica e profissional teve um grande estímulo nessa conjuntura. Sabe-se que um dos aspectos decisivos para a vinda das empresas foi a existência de uma unidade do Serviço Nacional de Aprendizagem Industrial - Senai, que tem garantido a qualidade da mão-de-obra e servido como porta de entrada para o novo operariado. O bom nível de escolarização em Resende também é atribuído historicamente à presença da Academia Militar das Agulhas Negras e da influência militar sobre a vida do município. Dentre outros aspectos a serem lembrados, é válido ressaltar a atuação de bons professores oriundos da Academia que fizeram elevar o padrão de qualidade das escolas. No atual momento, há um claro movimento no sentido de aumentar a oferta de ensino superior. Novos cursos em faculdades pública e privada apontam para uma demanda cada vez maior por profissões relacionadas com as necessidades atuais do mercado de trabalho industrial. No âmbito regional, a criação de uma Universidade Federal no Sul Fluminense, baseada no modelo da existente em Volta Redonda, foi recentemente anunciada pelo Ministério da Educação.

Iniciativas com vistas a criar condições para outros novos investimentos, a proveitando o impulso econômico trazido pela indústria automotiva, têm se manifestado no universo regional, incluindo as áreas industriais mais antigas, em busca de novas vocações ou de uma melhor adaptação à realidade industrial transformada pela reestruturação 
empresarial que atingiu a todas ao longo dos anos 1990. A referência é a região mais ampliada incluindo principalmente outros de seus mais ativos municípios - Volta Redonda e Barra Mansa, mas também Piraí e Barra do Piraí.

$\mathrm{Na}$ imprensa, o relato das atividades empresariais do Sindicato das Indústrias Metalúrgicas, Mecânicas e de Material Elétrico do Sul Fluminense - MetalSul reconhece o dinamismo econômico da nova conjuntura e identifica pautas pouco comuns até recentemente, como o convite ao diálogo entre capital e trabalho em prol do desenvolvimento local.

“MetalSul propõe apoio a empresas locais - Um dos objetivos de Roberto Balbi, recém-eleito presidente do Sindicato das Indústrias Metalúrgicas, Mecânicas e de Material Elétrico do Sul Fluminense (MetalSul), é dialogar com as prefeituras locais para que elas passem a dar facilidades e incentivos (também) para as empresas que já estão estabelecidas na região [...]. O dirigente sindical [...] conta obter o apoio do Sindicato dos Metalúrgicos para essa iniciativa: 'Se empregadores, empregados e poder público se unirem com um mesmo objetivo, tenho certeza de que todos na região poderão sair ganhando', disse. Balbi acredita, também, que o relacionamento entre patrões e empregados, assim como entre empresas e governos e entre as diversas empresas, está passando por transformações. - Acredito que não só a região, mas todo o mundo, está entrando em uma era em que a solidariedade passa a ser uma questão de sobrevivência [...]" (Diário do Vale, 5/10/2001).

Nos outros exemplos (Diário do Vale, 2002; 2004), pode-se identificar também o empenho de políticos locais - deputados, prefeitos, secretários - associados à administração estadual, na elaboração de programas de incentivo ao desenvolvimento metal-mecânico e na tentativa de criar condições para uma maior integração entre as empresas locais.

“Empresas irão oferecer serviços a grandes indústrias - O prefeito (de Resende) Eduardo Meohas e o secretário municipal de Indústria, Comércio e Turismo, Antônio Gastão, lançaram ontem o Programa Missão Empresarial. O evento [...] teve como proposta cadastrar empresas do município para oferecerem serviços e peças às grandes companhias sediadas em Resende e região, como Volkswagen, Clariant, Peugeot, GalvaSud e Guardian. Segundo Gastão, esse programa busca ainda promover a integração entre as grandes, médias e pequenas empresas de Resende" (Diário do Vale, 13/12/2002). 
"Governo do Estado promove workshop para atrair investidores - A Codin (Companhia de Desenvolvimento Industrial do Estado do Rio de Janeiro) promove hoje na fábrica da Volkswagen Caminhões e Ônibus o 1ำ Workshop de Negócios Automotivos do Estado do Rio de Janeiro. O evento é promovido em parceria com o Sebrae/RJ, o Grupo de Produção Integrada da Coppe/UFRJ e a Rede de Tecnologia do Rio de Janeiro e tem o objetivo de atrair para o estado investidores do segmento que reúne fabricantes de carrocerias, semi-reboques, guinchos e caçambas graneleiras especiais. O workshop [...] é parte integrante do projeto Rio Automotivo. [...] Segundo o presidente da Codin, [...], foi justamente com [...] a finalidade de integrar a cadeia produtiva do setor automobilístico, fortalecendo, assim, o cinturão de fornecedores no Médio Paraíba, que a Codin formou um grupo para transformar o Sul Fluminense em um pólo de soluções para veículos comerciais e implementos rodoviários [...]" (Diário do Vale, 16/4/2004).

Políticas de caráter nacional, nos últimos anos, têm se efetivado localmente com o objetivo de facilitar a criação de novos micros e pequenos empreendimentos, com destaque para o papel desempenhado pelo Serviço Brasileiro de Apoio às Micro e Pequenas Empresas - doravante Sebrae, através de uma política de incentivo à formação de Arranjos Produtivos Locais - APLs. Essa estratégia se articula com outras iniciativas, principalmente de associações empresariais, como a Firjan. Nos exemplos a seguir retirados da imprensa encontram-se dois tipos de ação do Sebrae na região Sul Fluminense em áreas fundamentais para o crescimento econômico: uma que diz respeito à logística de transporte, tendo em vista a instalação das novas indústrias; e uma outra relativa ao significativo setor turístico dos municípios ao redor de Resende, nesse caso com uma clara preocupação de agregar diferentes setores da sociedade para discutir alternativas para o desenvolvimento local.

“Sebrae e Sulcarj debatem transporte-Sebrae vai apresentar [...] a pes-
quisa realizada pelo Instituto Genesis com pequenas e grandes empre-
sas embarcadoras de produtos sobre a necessidade de aprimoramento
dos serviços prestados pelas transportadoras de cargas da região. Inti-
tulado 'Médio Paraíba sobre Rodas', o evento é organizado em parceria
com o Sulcarj (Sindicato das Empresas de Transportes de Cargas do Sul
Fluminense) e a Aciap (Associação Comercial, Ind ustrial e
Agro-Pastoril). [...] De acordo com o gerente regional da Agência de De-
senvolvimento do Sebrae, Olavo Damasceno Ribeiro Filho, a necessi-
dade de discutir as formas da expansão das empresas de transportes é 
em função do aumento das exigências do mercado no setor de logística, com a instalação de indústrias como a Peugeot Citroen, GalvaSud e Guardian, em Porto Real [...]"(Diário do Vale, 24/5/2000).

"Fórum de Desenvolvimento Local destaca importância do turismo Uma parceria entre o Sebrae (Serviço Brasileiro de Apoio às Micro e Pequenas Empresas), a prefeitura municipal e a FGV (Fundação Getúlio Vargas) [...] promoveu o primeiro Fórum de Desenvolvimento Local em Itatiaia. [...] O objetivo [foi] reunir diversos segmentos da sociedade, associações de moradores e de classe, como entidades hoteleiras, visando a encontrar alternativas para o desenvolvimento local e econômico do município. 'É importante que haja a participação da comunidade na discussão de alternativas. A realização do fórum é o primeiro passo. Vamos articular parcerias para que essas propostas possam acontecer', ressaltou a coordenadora do projeto pela prefeitura, Alessandra Arantes Marques. [...]" (Diário do Vale, 25/8/2002).

O governo estadual tem utilizado suas instituições e programas no esforço de atrair mais investimentos para o Sul Fluminense. Suas principais atividades vem se dando através da Codin, que se utiliza do Fundo de Desenvolvimento Econômico e Social - Fundes para operacionalizar a estratégia de implantação de novas iniciativas ${ }^{13}$. Uma das diretoras da Codin explica o funcionamento da instituição no caso da indústria automotiva do Sul Fluminense e comenta as características do incentivo à colaboração oferecido pelo governo estadual.

"O que a gente tenta é levar sempre um projeto que tenha sinergia com a região. [...] Qualquer projeto que venha e que a gente perceba que é Sul Fluminense, a gente envolve todos os municípios do Sul Fluminense e manda um fax [...] e diz: estamos negociando um projeto para fazer isso, que precisa de uma área X [...], enfim começo a dar as diretrizes e peço para cada um deles se pronunciar com relação às alternativas. Cada um deles me manda ou não, e quem manda a gente monta o tal quadrinho, apresenta à empresa e mando cópia pro município: segue em anexo cópia do quadro de alternativas apresentado para empresa" (Roberta Maia, Codin, 2002)".

Outros órgãos da administração pública também têm interferido na formulação de alternativas, abordando aspectos centrais para a sustentabilidade do desenvolvimento local, especialmente no que diz respeito ao meio ambiente. Uma particular preocupação com a qualidade e o uso das águas do Rio Paraíba do Sul, por exemplo, estimulou a criação do Comitê para Integração da Bacia Hidrográfica do Rio Paraíba 
do Sul - Ceivap, por decreto federal em 1996, que tem seu escritório-sede na cidade de Resende, $\mathrm{RJ}^{14}$. Outro exemplo foi a assinatura de um "termo de cooperação técnica" entre a Firjan e a Fundação Estadual de Engenharia do Meio Ambiente - FEEMA/Codin para a implantação do "Programa de Ecopólos do Sul Fluminense", "em prol do desenvolvimento socioeconômico do Sul do Estado" (Diário do Vale, $29 / 11 / 2002)$.

\section{NOVAS INDÚSTRIAS E MERCADO DE TRABALHO LOCAL}

A estrutura do mercado de trabalho ganhou novas características e se complexificou com as exigências das montadoras. Embora os empregados requisitados tenham ido majoritariamente para a linha de produção e para os serviços acessórios ao funcionamento das fábricas - segurança, alimentação, limpeza, transporte etc. -, e não para os cargos de gerência mais elevada, e embora a tendência esteja sendo de contratar cada vez mais mão-de-obra local para os cargos de gerência intermediária, a demanda inicial foi por uma mão-de-obra escolarizada e com formação técnica básica. No entanto, pode-se constatar um crescimento também de outros tipos de emprego, tanto na construção civil como no setor de serviços (principalmente turismo). Aumentou a demanda por casas e apartamentos, novos hotéis para executivos, melhores restaurantes e serviços no comércio ${ }^{15}$. Com entrada em funcionamento do conjunto de empresas ligadas ao setor automotivo, pode-se dizer também que está se formando um "mercado interno de mãode-obra", com trabalhadores se alternando entre as empresas.

A formação de uma nova classe operária industrial, ligada à indústria de veículos, altera o perfil do operariado metalúrgico regional. A história dos metalúrgicos de Volta Redonda remonta aos anos 1940 com a criação da CSN e reflete as várias fases do movimento sindical regional e nacional, assim com as diferentes fases pelas quais passou a empresa. A privatização da CSN em 1993 e o enxugamento de sua operação industrial, resultando na redução de milhares de postos de trabalho, colocaram dilemas para o sindicato e também para a cidade, a qual começou a enfrentar não só as mazelas oriundas do desemprego, como também a necessidade de criar alternativas econômicas no sentido de habilitar o mercado de trabalho local para a nova realidade da "produção enxuta". No caso de Resende, a questão está em compreender o perfil do operariado exigido por esse tipo de produção, assim como a condição de sua sustentabilidade. Pergunta-se em que nível de precariedade 
está colocado esse tipo de emprego e se é possível criar mecanismos que assegurem a manutenção dos novos empregos criados.

Uma das principais características das novas empresas instaladas, a de serem "fábricas enxutas", portanto estruturadas de modo a não precisarem manter uma grande concentração de trabalhadores e de não criarem muitos empregos diretos, talvez seja um dos aspectos mais interessantes a serem considerados. Não se trata aqui de locais que tenham sofrido com a reestruturação das empresas e que tenham tido que negociar a crise que se abateu sobre o seu mercado de trabalho. Em Resende (e Porto Real), as demandas sobre o mercado de trabalho foram crescentes - embora não na quantidade imaginada pela sociedade local -, exigindo além de tudo, um tipo de trabalhador preparado para atender às necessidades específicas da produção de veículos. Nesse sentido, houve inicialmente um movimento duplo: por um lado, a VW trouxe gente do $\mathrm{ABC}$ para suprir determinadas necessidades que não estariam disponíveis localmente. Por outro, houve um intenso movimento do Senai local no sentido de recrutar e formar o mais rápido possível trabalhadores para as novas práticas produtivas, o que ocorreu de modo satisfatório do ponto de vista da empresa (Rocha, 2002). No caso da PSA Peugeot Citroën, que foi inaugurada cinco anos depois da VW em 2001, não só o mercado de trabalho específico já estava formado como a empresa e suas fornecedoras, em convênio com o Senai local, se ocuparam previamente do treinamento de trabalhadores para a linha de montagem.

Pode-se dizer que atualmente está constituído um importante mercado de trabalho voltado para a indústria automotiva. E, curiosamente, o perfil desse trabalhador, se pudermos tomar a VW como exemplo (Ramalho e Santana, 2001), é de homens jovens, escolarizados (ensino médio completo), formados pelo Senai, moradores de Resende, e sem experiência prévia de trabalho em atividades industriais de qualquer tipo. A formação de uma classe operária local tem trazido vários desdobramentos positivos, tanto no que diz respeito ao crescimento das atividades sindicais, como também no que diz respeito ao tipo de demanda econômica, política e social que essa "nova" população passou a ter e buscar na cidade e na região - educação superior, habitação, lazer, segurança, saúde e consumo. Esse perfil revela um paradoxo e confirma uma das características de experiências de tipo green-field. Afinal de contas, Volta Redonda e Barra Mansa, municípios vizinhos e com mercados de trabalho já experientes em termos industriais, tendo in- 
clusive uma situação de aumento da oferta de mão-de-obra devido à reestruturação da siderurgia regional, não foram praticamente acionados no processo de recrutamento de trabalhadores para a nova indústria automotiva. Depoimentos de gerentes da VW confirmam a intenção de buscar realmente operários com pouca experiência anterior - inclusive sindical - e que pudessem ser moldados aos objetivos de ter um trabalhador flexível e adaptável aos processos produtivos que estavam sendo instalados.

\begin{abstract}
"A indústria automobilística junto com o SENAI financiou a formação e a qualificação do profissional. [...] Hoje, você pega uma cidade como Resende, você consegue fazer uma fábrica como a Peugeot, ou Volkswagen [...]. Aqui em Resende você [...] tem uma série de vantagens com essa característica de uma população com um nível de escolaridade adequado que permite a gente criar uma operação flexível com baixo custo, competitiva, sem estar muito preocupado se essa região tem uma tradição sindical ou não. Acho que essa não é a maior preocupação, não, pelo contrário. A preocupação está em procurar locais onde eu consiga ter uma estrutura de baixo custo e até pra estimular o desenvolvimento." (B.C., gerente de Recursos Humanos-VW de Resende, 2002)
\end{abstract}

Outro aspecto se relaciona com o valor dos salários pagos pelas empresas. O preço do trabalho foi desde o início uma das principais razões para a busca de novas locações por parte da indústria automobilística durante os anos 1990. Mas diante das críticas dos sindicatos no âmbito nacional, as empresas argumentaram pela defasagem também existente entre os preços dos produtos essenciais dentre as regiões mais tradicionais e as regiões com a presença recente da indústria. Para dirimir essas dúvidas, o Departamento Intersindical de Estatística e Estudos Sócio-Econômicos - DIEESE, com o apoio do sindicato dos metalúrgicos do $\mathrm{ABC}$, realizou um levantamento em dezessete municípios onde há fábricas produtoras de veículos no país (inclusive Resende/Porto Real), coletando mais de 5 mil preços, em 470 pontos comerciais. Os resultados finais mostraram que se por um lado há grandes diferenças de remuneração entre os dezessete municípios, por outro, há uma convergência na maioria dos preços e serviços, com exceção dos preços dos terrenos, aluguéis e educação (Dieese et alii, 2003:11). Mesmo nessas condições, pode-se dizer que essa nova classe operária fluminense introduziu um padrão salarial e de consumo que teve evidentes conseqüências no comércio e na política local, e que sua média salarial se coloca acima da média salarial da região. 


\section{ORGANIZAÇÃO SINDICAL E CULTURA METALÚRGICA}

Os novos empregos foram muito bem-vindos pela organização sindical dos metalúrgicos que tinha pouca experiência no setor automobilístico e parecia não ter capacidade organizativa para mobilizar o novo contingente de trabalhadores. Mas o sindicato também construiu sua prática e sua ação política tendo como fonte de inspiração uma "cultura metalúrgica" associada especialmente a CSN, em Volta Redonda-RJ. A instalação das fábricas em Resende e Porto Real representou uma mudança nas características dessa "cultura", e no desempenho do sindicalismo regional. Segundo Carlos Perrut,

\footnotetext{
"A gente tinha uma política sindical muito ligada à CSN, que é uma grande empresa. [...] A gente tinha essa cultura metalúrgica. [...] Com a vinda primeiro da Volks [...] foi uma coisa inovadora [...]. Por quê? A gente não sabia disso...o sistema de funcionamento da Volks é único no mundo, é o sistema modular. [...] Houve esse impacto de serem módulos... então, a princípio, nós tivemos um choque de comportamento em relação à CSN" (Carlos Perrut, presidente do sindicato dos metalúrgicos do Sul Fluminense, Volta Redonda, 2001).
}

A atividade e a participação sindical metalúrgica cresceram em quantidade e qualidade após a vinda das empresas da indústria automotiva. De uma inexpressiva extensão do sindicato baseado em Volta Redonda, a subsede de Resende ganhou expressão e peso político com o aumento significativo do número de operários empregados pelas montadoras. Ao contrário da região tradicional do $\mathrm{ABC}$ paulista, que passou nos anos 1990 pelos percalços de um processo de reestruturação dentro das firmas, o caso de Resende (e Porto Real) notabiliza-se pelo fato de que as novas empresas já se constituem em um modelo reestruturado, o que acaba afetando as estratégias de ação do sindicato local. A flexibilização das atividades produtivas já foi colocado como um dado (nunca esteve em discussão) e, apesar do discurso empresarial enfatizar a importância da participação dos trabalhadores para o bom andamento do processo produtivo, o sindicato tem sofrido com um cerceamento de suas atividades dentro das empresas (principalmente na PSA Peugeot Citroën) (Ramalho, 2004).

Embora houvesse inicialmente falta de experiência de negociação salarial e outros itens relativos à pauta das montadoras, as características da cadeia automotiva têm permitido um interessante processo de rápi- 
da socialização de práticas sindicais no Brasil e no exterior, de modo a integrar os operários metalúrgicos de Resende (e Porto Real) à problemática mais ampla desse ramo industrial. Os metalúrgicos da VW e da PSA Peugeot Citroën e sua liderança sindical local (Pereira, 2003) estiveram bastante ativos desde os primeiros anos, apelando inclusive para paralisações parciais e uma greve de uma semana, em 1999 (Ramalho e Santana, 2001) quando conquistaram o direito de ter uma comissão de fábrica eleita periodicamente pelos trabalhadores e presente cotidianamente no interior dela (Francisco, 2004). A fábrica da VW de Resende foi também a escolhida para iniciar o conjunto de paralisações do que ficou conhecido em 1999 como o "Festival de Greves", movimento que reuniu as principais centrais sindicais na demanda por um contrato nacional para os trabalhadores das montadoras que compensasse as defasagens salariais estabelecidas pela reespacialização da indústria automotiva. Além disso, a rede mundial estabelecida pelos trabalhadores da VW consegue ter um efeito socializador importante em Resende, articulando e informando os operários locais das principais demandas e inibindo práticas autoritárias no chão-de-fábrica. No caso da PSA Peugeot Citroën, as relações com o sindicato têm sido mais ríspidas, e, desde a sua inauguração, sucessivos contenciosos têm sido criados resultando inclusive em uma curta greve em 2003.

A participação do sindicato no debate sobre desenvolvimento ainda tem sido pequena, embora seja possível notar que essa problemática já faz parte de suas preocupações. O impacto da presença das grandes empresas sobre os operários e o sindicato local parece fortalecer essa instituição e aumentar o poder de pressão dos operários não só sobre as empresas mas também sobre as municipalidades, reivindicando participação nas decisões referentes a políticas sociais e desenvolvimento econômico.

Dentre os organismos estimulados pela nova conjuntura que possibilitam essa participação, está a Comissão Municipal de Emprego, fórum que supõe a congregação de diferentes setores econômicos e políticos locais, inclusive representações sindicais.

“É Comissão Municipal de Emprego [...] então qual é a nossa atuação: nós já fizemos projeto que no ano passado [...] nós conseguimos [...] quatrocentos e alguma coisa [...] trabalhadores treinados com verba que nós negociamos, que nós fizemos projeto [...] do Fundo de Amparo ao Trabalhador [...] nós já formamos muitos desses aí, e nós não busca- 
mos dizer: foi o sindicato, não [...] nós temos uma atuação em vários setores e esse é um dos setores" (Isaac Moraes, diretor do sindicato dos metalúrgicos em Resende, 1999).

E o sindicato tem aparecido também na discussão sobre formas de atração de novos investimentos, assim como sobre a necessidade de uma ação regional conjunta e coordenada de modo a potencializar a presença de empresas como as da indústria automotiva. As iniciativas ainda são tímidas, se comparadas com a atividade sindical do $A B C$ nesse aspecto, mas parecem indicar que o sindicato tem se sentido ao menos pressionado a se posicionar no debate. A notícia a seguir revela, por exemplo, uma preocupação do sindicato dos metalúrgicos com a modernização das empresas da região tendo em vista a necessária adaptação às demandas das novas empresas instaladas.

\begin{abstract}
“Volta do 'cinturão' depende de ISO 9000 - A volta do 'cinturão' das empresas fornecedoras da CSN depende diretamente da implantação da ISO 9000. A afirmação é do presidente do Sindicato dos Metalúrgicos, Carlos Henrique Perrut, que acentuou ontem a mudança na denominação do 'cinturão', que passa a ser chamado de consórcio; e do alvo, que antes era a CSN e agora é toda empresa de expressivo porte na região Sul Fluminense. [...] 'Queremos ampliar nossa capacidade de atendimento e revitalizar as empresas', comentou o sindicalista. Empresas como a Galvasud - joint venture da CSN e da ThyssenKrupp-, a Volkswagen, a INB (Indústria Nuclear Brasileira, a Michelin, a Xerox, a Barbará, a SBM (Siderúrgica Barra Mansa) e a Peugeot Citroën serão alvos do consórcio das empresas fornecedoras da região. [...]" (Diário do Vale, 16/8/2000).
\end{abstract}

Falando sobre o tema, o presidente do sindicato coloca-se como parte integrante de uma situação que exige cooperação para viabilizar o crescimento econômico:

\footnotetext{
"Se a gente colocar todos os prefeitos numa mesa e se não tiver corporativismo, a gente tem condições de fazer um trabalho em curto prazo e alavancar muito mais essa região. [...] Nós temos que usar o nosso potencial que é muito grande e convergir para que esse desenvolvimento aconteça. [...] Acho que é papel do sindicato trabalhar isso também" (Carlos Perrut, presidente do sindicato dos metalúrgicos do Sul Fluminense, Volta Redonda, 2001).
} 


\section{O ACÚMULO REGIONAL DE RELAÇÕES POLÍTICAS}

Para falar da participação de redes sociopolíticas nesse contexto industrial, deve-se ressaltar a formação recente, mas significativa, de uma classe operária metalúrgica. Novos valores associativos e de identidade oriundos dessa prática operária e sindical colocam-se como fatores que diferenciam rapidamente a região, trazendo também novos tipos de demanda tanto para as empresas e mercado de trabalho local, como para as instâncias que lidam com a vida da cidade e dos bairros, representando um modo diferente de exercer sua cidadania municipal. Por outro lado, Resende e os municípios vizinhos vivenciaram uma história de ação de movimentos sociais nas últimas décadas, assim como hoje a ação dos movimentos sociais em âmbito regional tem crescido de qualidade e se complexificado em termos de novas pautas de reivindicações. No contexto atual de estímulo ao desenvolvimento local e regional, a sociedade civil tem sido chamada a participar, embora de forma tímida. As demandas sociais, no entanto, têm estado ligadas a essa nova fase industrial no sentido principalmente do uso dos recursos públicos gerados por essas atividades.

Um dos aspectos que pode interferir na constituição de novas ou renovadas instituições voltadas para a discussão do desenvolvimento é a consideração das redes sociopolíticas construídas nas localidades e do acúmulo de experiências políticas voltadas para a participação da sociedade civil nos processos de decisão. A inclusão da sociedade civil deve ser tida como elemento necessário para captar a natureza das mudanças pelas quais passam as instituições. E isso requer, como afirmam Locke e Jacoby (1997:59), "que examinemos mais cuidadosamente as características qualitativas da sociedade civil (i.e, os atributos organizacionais de grupos diferentes e os padrões de interação entre eles) de modo a melhor entender como esses diferentes padrões moldam o comportamento de maneiras distintas".

$\mathrm{Na}$ avaliação da capacidade local e regional de se articular para criar novos fóruns de discussão e implementação do desenvolvimento econômico e social, é preciso considerar também a história regional e local no que diz respeito às redes sociais e políticas e o acúmulo organizacional que pode influenciar nesse novo momento da conjuntura no sentido de reforçar - ou dar uma base de sustentação - a participação dos sindicatos e movimentos sociais e, com isso, estabelecer novos parâmetros que aprofundem as práticas democráticas. Em Resende (e Por- 
to Real), esse acúmulo organizacional - ou de capital social - tem uma história associada à intensa presença da Igreja Católica na região Sul Fluminense, durante o período de bispado de Dom Waldyr Calheiros, o qual, ligado a postura mais progressista de uma igreja mais próxima dos pobres, estimulou, acolheu e formou agentes sociais ligados às mais diferentes problemáticas existentes na região. Matérias de imprensa e entrevistas realizadas chamam atenção para a organização de movimentos sociais voltados para os problemas da cidade (Associações de Moradores, movimentos de fiscalização da política local) e da terra rural (Movimento dos Trabalhadores Rurais Sem Terra - MST, Comissão Pastoral da Terra etc.) que se constituíram nos últimos trinta anos em formadores de opinião e constituintes de importantes movimentos sociais. O fato de Resende (e Porto Real), por um bom tempo, só contar com uma subsede do sindicato dos metalúrgicos prejudicou um diálogo mais profícuo, associado ao fato de que os setores políticos ligados à Central Única dos Trabalhadores - CUT e apoiados pela Igreja Católica se dividiram e perderam o controle do sindicato em Volta Redonda para a Força Sindical, no início dos anos 1990, e com isso reduziram o diálogo. No entanto, alguns exemplos confirmam o estoque de práticas organizacionais e a constituição de rede sociopolíticas.

Um deles vem da organização ativa das associações de moradores de Resende nos últimos vinte anos. A presença da Igreja católica é fundamental na implementação das atividades, mas os efeitos dessa militância parecem ter trazido para a localidade uma prática política de reivindicação bastante efetiva. No depoimento a seguir, o ex-presidente da Federação de Associações de Moradores mostra essa ligação:

"Eu comecei a participar mesmo do movimento, a ter uma consciência política a partir de 85, com a participação em grupos jovens, e naquele período os grupos jovens e a linha da Igreja Católica, teologia da libertação, estavam contribuindo para suscitar militantes para o movimento sindical e para o movimento popular. E o movimento popular que é mais presente é o movimento de bairro, associação de moradores. Aqui em Resende, eu em 85 participei da oposição sindical dos bancários [...] e logo depois, [...] me tornei presidente da Famar, Federação das Associações de Moradores. [...] Eu participava ao mesmo tempo das comunidades, das assembléias aqui em Resende, ao nível de diocese,do bispo Waldir e tinha uma organização das comunidades de base, discutindo a formação de grupos de base e ao mesmo tempo discutindo as associações de moradores. [...] Então naquele período começou a surgir o 
movimento negro, quer dizer, a gente passou a ver o movimento de mulheres, a participação nas associações e paralelo a isso algumas leis foram aprovadas, cuja regulamentação tinha de ser nos municípios, como o estatuto do direito da criança e do adolescente. A gente tinha que organizar aqui em Resende o conselho municipal dos direitos da criança e do adolescente e conselho tutelar. A lei do SUS, que para receber uma verba pública tinha que organizar o conselho municipal e as conferências, e a discussão do plano diretor de desenvolvimento urbano" (Rogério Coitinho, ex-presidente da Federação das Associações de Moradores de Resende, 2002).

Outro fator de acumulação de experiência política e organizacional está relacionado com o problema da disputa por terras em Resende. No relato de um dos seus organizadores e vereador do município de Resende, essa história recente fica bem clara.

\begin{abstract}
"Houve um problema de terra aqui em Resende. [...] Lá estava acontecendo o seguinte: tinha os trabalhadores que estavam há anos tomando conta de uma terra com o consenso do dono desta terra, [...] e eles davam a terça parte do produto como aluguel da terra. O que aconteceu? Quando estava faltando um mês para a colheita do feijão, [o dono] pediu a terra de volta. Eles pediram para ele esperar um mês para colher o feijão, [...] mas colocou um trator e acabou com o feijão. Aí na verdade, eles entraram na justiça como arrendatários que queriam indenização pelo feijão. [...] Isso foi mais ou menos 90, 91. E a coisa engrossou mesmo [...]. Quem ajudou muito nisso também na época foi o presidente do sindicato dos trabalhadores rurais" (Franco Fagiam, ex-padre e vereador do município de Resende, 2002).
\end{abstract}

Interessante ainda notar a ligação dos movimentos sociais com a política partidária na última década. A ascensão ao poder de partidos mais sensíveis às demandas populares tem sido uma característica da região Sul Fluminense nos anos recentes, particularmente o Partido dos Trabalhadores - PT e o Partido Socialista Brasileiro - PSB que se transformaram em referências políticas em boa parte dos municípios. A prefeitura de Resende, nos últimos oito anos, tem estado nas mãos desses partidos. Na última administração do PT em Resende, por exemplo, criou-se uma secretaria voltada para os movimentos sociais. O depoimento de dois de seus responsáveis confirma uma proximidade entre o poder público e os movimentos sociais. 
“Aqui em Resende acompanha dois degraus abaixo Volta Redonda. Porque a Diocese foi a grande organizadora, fomentadora desses movimentos sociais, inclusive os próprios movimentos sindicais. E nós tivemos então naqueles anos oitenta uma valorização da questão das associações de moradores. Aí se organizam associações de moradores quase na cidade toda. [...] E algumas reivindicações vão passar a ser uns marcos desses movimentos. A luta pela taxa de iluminação pública isso foi uma grande mobilização, passeata [...] (Isso foi quando?) A vitória da TIP foi em noventa e três. Teve Plano Diretor [...] teve várias lutas de criação do Conselho Municipal de Saúde [...]" (Paulo César da Silva, secretário municipal de movimentos sociais de Resende, 2002).

Essa ligação tornou também mais comuns iniciativas que têm levado em consideração a participação de organizações da sociedade civil e outros movimentos políticos nas decisões políticas locais. Políticas de consulta a população podem ser constatadas nos dois exemplos seguintes, ocorridos em Resende:

\footnotetext{
"Iniciada discussão sobre orçamento participativo - No próximo sábado, a prefeitura [de Resende], por meio da Secretaria Municipal de Cidadania e Relações Comunitárias, estará discutindo pela primeira vez esse ano o orçamento participativo do município. [...] Nesse primeiro encontro iremos apresentar para cerca de 58 representantes de associações de moradores o trabalho realizado no ano passado. Vamos aproveitar também para realizar a eleição do Conselho Municipal do Orçamento Participativo, onde cada associação poderá indicar um conselheiro - disse o secretário, Paulo César da Silva explicando que o Conselho será responsável por acompanhar todas as etapas do Orçamento Participativo, inclusive a execução das obras indicadas pela população" (Diário do Vale, 11/3/2003).

"Prefeitura promove segunda edição do projeto 'AGIR' - A Prefeitura de Resende realiza [...], no Parque Paraíso, a segunda edição do projeto AGIR (Ação Global de Impacto em Resende). [...] A programação prevê [...] a posse do Conselho Local de Segurança, instrumento que garante a participação popular no Plano Municipal de Ordem Pública [...]" (Diário do Vale, 12/9/2003).
}

Há também políticas de incentivo a militância, como no exemplo abaixo em que a prefeitura de Resende se envolve diretamente com a discussão sobre a questão da comunidade negra do município. 
“Comunidade Negra de Resende promoverá encontro no sábado - A Secretaria Municipal de Cidadania e Relações Comunitárias de Resende promoverá no próximo sábado o II Encontro da Comunidade Negra de Resende. [...] Segundo a coordenadora municipal da comunidade negra, Sônia Freitas, o evento contará com a participação do professor Roberto Henrique dos Reis, defensor público de Itatiaia e Porto Real, que tratará sobre leis contra o racismo. Durante o encontro, será discutida também a implantação do SOS Racismo em Resende. [...] De acordo com Sônia, o projeto tem como objetivo aumentar a auto-estima da comunidade negra" (Diário do Vale, 11/7/2003).

Como resultado da intensa participação da Igreja junto aos movimentos sociais, novos tipos de demanda política começaram a surgir nos últimos anos, de certa forma trazendo novas demandas e atuando em outras frentes, como é o caso do Movimento pela Ética na Política MEP, oriundo da militância de Igreja, que, a partir de Volta Redonda, irradia preocupações e atos políticos para toda a região. Na verdade, ética na política é um nome geral que expressa um conjunto mais amplo de temas que passaram a ser debatidos no âmbito regional.

"MEP comemora seis anos de trabalho - Após uma denúncia feita pelo DIÁRIO DO VALE, em janeiro de 1997, sobre a criação de 72 novos cargos sem concurso na Câmara Municipal, um grupo de pessoas ligadas a movimentos sociais, comunidades e pastorais da Igreja Católica decidiu se mobilizar para cobrar moralidade, transparência e ética do Poder Legislativo. Nascia, assim, o MEP (Movimento pela Ética na Política), que comemora seis anos de atuação no município na próxima quinta-feira, dia 6 de fevereiro. [...] Impulsionado pelo objetivo de buscar a moralidade, a transparência e a ética na política, além de incentivar a cidadania da população, o MEP realiza ações de acompanhamento dos poderes públicos, pesquisas e sondagens populares, projetos educacionais voltados à comunidade, atos públicos de manifestação e estudos sobre assuntos diversos" (Diário do Vale, 2/2/2003).

\section{CONCLUSÃO}

A análise da implantação da indústria automotiva na região Sul Fluminense, principalmente nos municípios de Resende e Porto Real, revela alguns dos efeitos mobilizadores do processo sobre os diversos segmentos da sociedade local e regional, levando-os a tentar adaptar o 
novo ciclo industrial a seu favor. Pode-se então especular sobre os elementos que propiciam a emergência desses efeitos:

- Uma conjuntura econômica nacional que possibilitou a criação de novos espaços produtivos para a indústria automotiva através, principalmente, de uma política de incentivos fiscais, ao mesmo tempo em que tornou possível a socialização da experiência de antigos espaços industriais reestruturados;

- Uma conjuntura econômica estadual e municipal que fez com que vários agentes vislumbrassem na vinda da cadeia automotiva uma forte oportunidade para a revitalização da região;

- A atuação de órgãos públicos estaduais que criaram mecanismos de facilitação de políticas de agregação industrial (através de planejamento e incentivos fiscais);

- O fato de a região ter experimentado um processo de flexibilização da produção e da mão-de-obra através do caso precedente de privatização e reestruturação de uma grande indústria já existente (CSN em 1993);

- O aumento dos Produto Interno Bruto - PIBs municipais, nos últimos anos, assim como demandas por serviços públicos em geral, que levou a compreensão por parte dos governos municipais das vantagens econômicas e políticas que poderiam resultar da chegada das empresas (a "vocação metal-mecânica" parece ter sido abraçada por todos, associada à busca pela criação de empregos);

- A compreensão e implementação como política de uma atitude de integração e cooperação entre empresas e sociedade (por parte de entidades como a Firjan e o Sebrae). A região tem sido pensada como um todo nesse contexto, em uma tentativa de quebrar o natural "egoísmo" municipal. A ênfase tem sido a de buscar caminhos para uma integração entre as atividades das pequenas e médias empresas e a das grandes empresas, ou de aproveitar da melhor forma o surgimento de outras possibilidades empresariais, subprodutos do crescimento econômico industrial, como o turismo e os serviços;

- A presença de movimentos sociais locais, com acúmulo de força política oriunda de lutas reivindicatórias das últimas décadas (não só Resende e Porto Real, mas todo o Sul Fluminense); 
- A presença marcante, na sociedade civil, de instituições fortes de sustentação dos movimentos sociais cada vez mais voltados para a fiscalização dos políticos locais e para as reivindicações urbanas de habitação, saúde, saneamento, educação e segurança (Igreja, MST, Comissão Pastoral da Terra-CPT);

- A formação de um contingente operário expressivo, com características comuns de escolarização, idade e formação profissional, socializado em um ambiente de trabalho de grande empresa multinacional e automotiva, com um importante impacto nas localidades em termos econômicos e políticos;

- Uma rearrumação da atividade sindical metalúrgica que ganhou um grande contingente de novos operários. Ainda se adaptando a novidade da experiência industrial automotiva, o sindicato já deu demonstrações de que pode ter uma atuação efetiva na defesa dos interesses dos operários fabris e no que diz respeito às discussões sobre o desenvolvimento local, embora ainda não tenha uma presença efetiva em todos os fóruns já constituídos, já se manifestou quanto à oportunidade dessas atividades e quanto a sua intenção de integrá-las. Nesse contexto, a experiência de outras regiões ligadas à indústria automotiva, como é o caso do ABC paulista, acaba servindo como exemplo de participação nas atividades relativas ao destino das localidades;

- Finalmente, um esforço regional e local dos atores políticos no sentido de articular mecanismos de governança, apesar das condições adversas relacionadas às motivações oportunistas das novas empresas, se aproveitando da sinergia produzida pelas novas atividades econômicas para buscar alternativas de cooperação entre os novos e antigos agentes de desenvolvimento econômico e social.

A contribuição desse caso para uma discussão mais geral sobre experiências de política industrial e desenvolvimento local está em apontar indícios de que os efeitos da presença de grandes empresas globalizadas em contextos locais podem resultar também em uma mobilização positiva da sociedade e na constituição de mecanismos de negociação sobre a utilização dos benefícios gerados pelas atividades industriais. A cooperação entre (pequenas) empresas tem sido a principal ênfase do debate atual sobre estratégias de desenvolvimento industrial em contextos locais, tomando-se quase sempre como exemplo a experiência dos distritos industriais italianos - paradigmas do modelo da especialização flexível (Piore e Sabel, 1984). Desconsiderar a presença de 
grandes empresas em aglomerados industriais e o seu relacionamento com outras empresas e outras instituições estabelecidas no mesmo território, no entanto, tem sido um problema para a análise de várias outras experiências industriais do mundo globalizado, especialmente aquelas que fazem parte de cadeias produtivas globais. No caso estudado (Sul Fluminense), as empresas apresentavam características iniciais opostas a uma perspectiva de cooperação e integração a realidade local. O próprio processo de escolha da região já confirma que, entre as razões principais das empresas, estava a expressiva generosidade fiscal oferecida pelas administrações públicas - municipal, estadual e federal - e a possibilidade concreta de alocar trabalhadores em níveis salariais inferiores aos de outras regiões semelhantes. Agrega-se a isso a construção de fábricas não só vinculadas às estratégias de suas matrizes no exterior e ligadas a uma cadeia global de firmas majoritariamente externas a região, como também estruturadas no modelo da "produção enxuta" (subcontratação, flexibilização das relações de trabalho etc.), nesse caso hostil ao sindicato e as demandas dos trabalhadores. Esses elementos não são particularmente estimulantes de qualquer parceria com as instituições e os atores econômicos e políticos em prol do desenvolvimento local.

O que foi examinado nas páginas anteriores, no entanto, fez ressaltar a complexidade desse novo contexto socioeconômico, que, independente da vontade das grandes empresas, tem tido o efeito de, por um lado, induzir a formulação de novas práticas com vistas a garantir a sustentabilidade econômica (articulação de pequenas e médias empresas com as grandes, preocupação com o meio ambiente, criação de novos fóruns de discussão sobre as necessidades da região e sugestão de alternativas tanto para empresas como para governos municipais); e, por outro lado, publicizar a discussão sobre as conseqüências desse novo perfil produtivo para as relações de trabalho, o mercado de trabalho, as políticas públicas municipais de educação, saúde e segurança, e para a sociedade civil organizada, principalmente as organizações de trabalhadores e os movimentos sociais. A ausência de uma história anterior de arranjos produtivos bem-sucedidos localmente, nesse caso, não parece ter sido um impeditivo para as iniciativas recém-implementadas, como seria de esperar. Ao mesmo tempo, a situação do Sul Fluminense confirma a importância da política como esfera fundamental de qualquer análise atual sobre localidades com aglomerados industriais, no sentido de compreender as concepções e estratégias dos atores econômicos locais e suas diferentes formas de articula- 
ção, na constituição de um padrão de desenvolvimento que implique na participação desse coletivo no controle das melhores opções para o uso dos recursos econômicos e políticos produzidos localmente, sem estar desconectado da problemática nacional.

(Recebido para publicação em outubro de 2004)

(Versão definitiva em maio de 2005)

\section{NOTAS}

1. Cf. Castells (1999); Boltanski e Chiapello (1999); Harvey (1992) entre outros.

2. Parte-se de uma concepção de localidade, na articulação com processos nacionais e internacionais de mudança na economia política, que, como diz Cooke (1989:296), não pode ser vista apenas como mera receptora de algo decidido em escala superior, mas que está ativamente envolvida na sua transformação, mesmo que não tenha controle total sobre seu próprio destino.

3. Cuja vantagem estaria na constituição de uma forte rede de (pequenas) empresas que, segundo Sengenberger e Pike (1999:103), através da especialização e da subcontratação, dividiriam entre si o esforço necessário para produzir determinados bens, já que a especialização induziria a eficiência, tanto individual como no plano do distrito, e a especialização combinada com a subcontratação promoveria a capacidade coletiva, resultando uma economia tanto de escala como de escopo.

4. O Novo Regime Automotivo nasceu no interior do Plano Real e tinha como principais objetivos: (1) manter em funcionamento as grandes montadoras e as indústrias de autopeças já instaladas no país; (2) reestruturar as empresas brasileiras do setor; (3) atrair novas companhias e estimular a construção de novas plantas e marcas; (4) consolidar o Mercado Comum do Sul - Mercosul e reforçar a posição do Brasil como seu ator-chave.

5. De acordo com Scott (1999:20-21), "como os sistemas de produção em massa existentes em diferentes partes do mundo continuam a reestruturar-se, de acordo com os princípios de produção pequena e fontes modulares, e como as aglomerações antigas (tal como a da região do $\mathrm{ABC}$ ) produzem crescentes deseconomias (aumentos de salários e de custos de terrenos, por exemplo), os mesmos sistemas mostram uma propensão à reorganização do local com novos investimentos, que tendem a ser dirigidos cada vez mais para outros locais green-field, onde suas vantagens competitivas podem ser recriadas em uma nova base geográfica".

6. Na interpretação de Arbix e Rodríguez-Pose (1999) e Arbix (2000), essas estratégias de desenvolvimento estariam levando a uma disputa predatória entre Estados e municípios, cujo único e grande perdedor seria o setor público. Para eles, a única razão efetiva para o engajamento na guerra fiscal estaria vinculada aos dividendos a serem 
colhidos pelos governantes com uma visão de que a atração de grandes empresas seria panacéia para o desenvolvimento econômico. Cardoso (2001:10) identifica outros aspectos importantes desse processo de descentralização: “a guerra fiscal explica o destino final de uma planta, mas não explica a decisão de descentralizar o investimento. [...] Novos entrantes e novas plantas de antigas companhias seguiriam, previsivelmente, a lógica dos novos investimentos em toda parte na indústria automotiva: a escolha de um green-field (com ausência de tradição sindical e de trabalho em montadoras, existência de infra-estrutura de apoio e para escoamento da produção, estabilidade política local, acesso a mercados consumidores, salários mais baixos do que nas regiões de tradição sindical, disponibilidade de força de trabalho qualificada etc.)".

7. Segundo Pacheco (1999:5) “está em curso sensível alteração na dimensão espacial do desenvolvimento brasileiro, em que uma possível continuidade da desconcentração das últimas décadas deve ser acompanhada pelo aumento da heterogeneidade interna das regiões brasileiras, com o surgimento de ilhas de produtividade em quase todas as regiões, crescimento relativo maior das antigas periferias nacionais e importância maior do conjunto das cidades médias perante as áreas metropolitanas".

8. A fábrica de ônibus e caminhões da VW em Resende, além de tudo, é a única fábrica da empresa para esse tipo de veículo no mundo. Resende adquiriu status de "marca" em função da criação do "consórcio modular", apresentado como novidade em termos de modelo de produção, que consiste em uma proposta radical de "terceirização" ao colocar os fornecedores dentro da fábrica e responsabilizá-los diretamente pela montagem dos veículos, repartindo investimentos, custos e riscos (cf. Abreu et alii 2000; Arbix e Zilbovicius, 1997).

9. "Região tem maior PIB / per capita do Estado - Os investimentos de empresas que estão se instalando na região já começam a render frutos para o Médio Paraíba. Com a vinda de empresas como a Peugeot Citroën, GalvaSud, fabricantes de autopeças, em Porto Real; a Volkswagen Caminhões e Ônibus, em Resende, [...], a região já é a primeira em PIB per capita no Estado. [...] Segundo os dados mais recentes, em 1999, a região do Médio Paraíba obteve o primeiro lugar com um PIB per capita de R \$11.258,00 contra a metropolitana, que foi de R $\$ 10.397,00$. [...] Ao todo são cinco municípios pertencentes ao Sul Fluminense que estão no ranking de maiores PIBs do Estado" (Diário do Vale, 10/5/2001).

10. Isso não se coloca para a CSN em Volta Redonda, empresa estatal construída no espírito de integração com a cidade, o mercado de trabalho, e que atraiu uma rede de outras empresas siderúrgicas.

11. No caso da VW especificamente, o governo estadual entrou com boa parte dos custos de infra-estrutura, um montante em torno de US $\$ 15$ milhões. As negociações para a implantação da PSA Peugeot Citroën foram diferentes, embora com a utilização dos mesmos mecanismos como doação de terras, incentivos fiscais, salários baixos, e uma infra-estrutura regional que atendia aos interesses de expansão da montadora. No que diz respeito à política de incentivos, o caso da montadora francesa revelou uma inovação - a participação do próprio Estado do Rio de Janeiro como sócio da empresa - cerca de 32\% de participação no seu capital (acrescido de um empréstimo substancial por parte do Banco Nacional de Desenvolvimento Econômico e Social -BNDES) (cf. Ramalho, 2002; Ramalho e Santana, 2001;2002).

12. Embora em um contexto industrial distinto, um movimento com essas características pode ser identificado em várias experiências no $\mathrm{ABC}$ paulista, como, por exem- 


\section{José Ricardo Ramalho}

plo, a da criação da Câmara Regional do Grande ABC (cf. Arbix, 2000; Leite 2003; Martin, 2001; Daniel, 2001; Jácome Rodrigues, 2004; Klink, 2003).

13. Segundo prospecto da Codin (2001), "estruturado em programas - setoriais, regionais e genéricos, o Fundo de Desenvolvimento Econômico e Social - FUNDES consiste na concessão de um financiamento equivalente a um percentual do faturamento incremental, gerado a partir da implantação do projeto, com taxas de juros reduzidas, de modo a assegurar as empresas investidoras condições adequadas à operação".

14. Segundo o resumo executivo do CEIVAP (2002:1), "o CEIVAP tem a atribuição de promover a gestão participativa dos recursos hídricos [...] e buscar a viabilização técnica e econômico-financeira de programas de investimento visando a recuperação ambiental e o desenvolvimento sustentável da bacia do rio Paraíba do Sul, garantindo a melhoria da qualidade de suas águas [...]".

15. “Varejo esbanja confiança em Resende - [...] O número de inscrições de novas empresas em Resende, incluindo lojas e registros de autônomos, chegou a 174 no primeiro semestre do ano [2004]. O restaurante Fogão de Lenha, há 16 anos na cidade, sentiu o aumento da concorrência com a abertura de três competidores no mesmo bairro de Campos Elísios, mas mesmo assim beneficiou-se da melhora da economia local. [...] O segmento que mais sentiu os efeitos do crescimento na economia, de acordo com o secretario Eduardo Campos, foi o das grandes lojas de utilidades e eletroeletrônicos [...]" (Valor Econômico, 23/8/2004). 


\section{REFERÊNCIAS BIBLIOGRÁFICAS}

ABREU, Alice, BEYNON, Huw e RAMALHO, José R. (2000), “The Dream Factory: VW's Modular System in Resende, Brazil". Work, Employment and Society, vol. 14, no 2. UK, Cambridge University Press.

ABREU, A., GITAHY, L., RAMALHO, J.R., e RUAS, R. (2000), “Produção Flexível e Relações Inter-firmas: A Indústria de Autopeças em Três Regiões do Brasil”, in A. Alice (org.), Produção Flexível e Novas Institucionalidades na América Latina. Editora da UFRJ, Rio de Janeiro.

ARBIX, Glauco. (2000), “Guerra Fiscal e Competição Intermunicipal por Novos Investimentos no Setor Automotivo Brasileiro". Dados, vol. 43, no 1, pp. 5-43.

e RODRÍGUEZ-POSE, Andrés. (1999), “Estratégias do Desperdício - A Guerra entre Estados e Municípios por Novos Investimentos e as Incertezas do Desenvolvimento". Novos Estudos CEBRAP, no 54 .

ARBIX, Glauco e ZILbOVICIUS, M. (1997), De JK a FHC - A Reinvenção dos Carros. São Paulo, Scritta.

BOLTANSKI, L. e CHIAPELLO, E. (1999), Le Nouvel Esprit du Capitalisme. Paris, Gallimard.

CASTELLS, Manuel. (1999), A Sociedade em Rede. São Paulo, Paz e Terra, vol. I.

CARDOSO, A. M. (2001), Reestruturação Sistêmica, Reespacialização e Relações Industriais na Indústria Automobilística Brasileira. Trabalho apresentado no seminário A Indústria Automobilística nas Américas: Os Novos Sistemas de Produção e a Reconfiguração dos Atores Produtivos. Rio de Janeiro, IUPERJ, 5-6 de março.

COCCO, G., GALVÃO, A. P. e SILVA, M. C. P. (1999), “Desenvolvimento Local e Espaço Público na Terceira Itália", in G. Cocco, A. Urani e A. Galvão (orgs.), Empresários e Empregos nos Novos Territórios Produtivos: O Caso da Terceira Itália. Rio de Janeiro, DP\&A Editora.

COMITÊ PARA INTEGRAÇÃO DA BACIA HIDROGRÁFICA DO RIO PARAÍBA DO SUL-CEIVAP. (2002). Resumo Executivo. Disponível no site < www.ceivap.org.br $>$.

COMPANHIA DE DESENVOLVIMENTO INDUSTRIAL DO ESTADO DO RIO DE JANEIRO - CODIN. (2001), Programa de Benefícios Financeiros e Fiscais. Rio de Janeiro. Manuscrito.

COOKE, Philip. (1989), “The Local Question - Revival or Survival?", in P. Cooke (org.), Localities - The Changing Face of Urban Britain. London, Unwin Hyman.

DANIEL, C. (2001), “Uma Experiência de Desenvolvimento Econômico Local: A Câmara Regional do Grande $\mathrm{ABC}$ ”, in N. Guimarães e S. Martin (orgs.), Competitividade e Desenvolvimento - Atores e Instituições Locais. São Paulo, Editora Senac.

DIEESE, CUT-CMN, Sindicato dos Metalúrgicos do ABC. (2003), Do Holerite às Compras Remuneração, Preços e Poder Aquisitivo do Tempo de Trabalho em 17 Municípios com Produção Automobilística no Brasil. São Paulo, SMABC.

FRANCISCO, Elaine M. (2004), A Comissão Enxuta: Ação Política na Fábrica do Consórcio Modular em Resende. Tese de Doutorado em Sociologia, Programa de 


\section{José Ricardo Ramalho}

Pós-Graduação em Sociologia e Antropologia. Universidade Federal do Estado do Rio de Janeiro, Rio de Janeiro.

GUIMARÃES, N. e MARTIN, S. (2001), “Descentralização, Equidade e Desenvolvimento: Atores e Instituições Locais", in N. Guimarães eS. Martin (orgs.), Competitividadee Desenvolvimento - Atores e Instituições Locais. São Paulo, Editora Senac.

HARVEY, David. (1992), Condição Pós-Moderna. São Paulo, Edições Loyola.

JÁCOME RODRIGUES, I. (2004), Sindicalismo e Desenvolvimento Regional: A Experiência dos Metalúrgicos do ABC. Trabalho apresentado no XXVIII Encontro Anual da Associação Nacional de Pós-Graduação e Pesquisa em Ciências Sociais ANPOCS. Caxambu, MG, outubro.

KLINK, Jeroen. (2003), “Secretaria de Relações Internacionais e Captação de Recursos da Prefeitura de Santo André: Novos Desafios através de uma Visão Estratégica". Global, $\mathrm{n}^{\mathrm{o}} 0$, janeiro.

LEITE, Márcia de Paula. (2003), Trabalho e Sociedade em Transformação: Mudanças Produtivas e Atores Sociais. São Paulo, Perseu Abramo.

LOCKE, Richard. (1995), Remaking the Italian Economy. New York, Cornell.

e JACOBY, W. (1997), “The Dilemmas of Diffusion: Social Embeddedness and the Problems of Institutional Change in Eastern Germany". Politics and Society, vol. 25, nํำ.

MARKUSEN, Ann. (1996), "Sticky Places in Slippery Space: A Typology of Industrial Districts". Economic Geography, vol. 72, no 3, pp. 293-313.

MARTIN, S. (2001), “Globalização e Imbricamento da Flexibilidade do Trabalho: Perspectivas Contemporâneas da Indústria Automobilística nas Américas (Brasil, México e Estados Unidos", in N. Guimarães eS. Martin (orgs.), Competitividade e Desenvolvimento - Atores e Instituições Locais. São Paulo, Editora Senac.

PACHECO, Carlos A. (1999), “Novos Padrões de Localização Industrial? Tendências Recentes dos Indicadores da Produção e do Investimento Industrial". Textos para Discussão, nำ 633, IPEA.

PEREIRA, Sergio M. (2003), Trajetórias Individuais e Ação Sindical no Pólo Industrial do Sul Fluminense. Dissertação de Mestrado em Sociologia, Programa de Pós-Graduação em Sociologia e Antropologia. IFCS/UFRJ, Rio de Janeiro.

PIORE, Michael e SABEL, Charles (1984). The Second Industrial Divide: Possibilities for Prosperity. New York, Basic Books.

PIRES, Elson. (2004), O Desenvolvimento Territorial na Integração: Estratégias, Instituições e Políticas. Projeto de pesquisa, DEPLAN/CEAPLA/IGCE/UNESP, São Paulo.

RAMALHO, J.R. (2002), Novas Formas de Organização Industrial, Desenvolvimento Regional e os Impactos sobre as Relações de Trabalho. Trabalho apresentado na II Conferência Internacional da ILAS-CEBRAP, Universidade de Columbia/São Paulo, 18-20 de março.

.(2004), “Novas Fábricas, Velhas Práticas: Relações Trabalhistas e Sindicais na Indústria Automobilística Brasileira". Caderno CRH, vol.17, no 41, pp. 41-52. 
eSANTANA, M.A. (2001), The VW's Modular System, Regional Development and Workers' Organisation in Resende, Brazil. Trabalho apresentado no 9o Colóquio Internacional da GERPISA. Paris, 7-9 de junho.

(2002), “A Indústria Automobilística no Rio de Janeiro: Relações de Trabalho em um Contexto de Desenvolvimento Regional", in M. R. Nabuco, M. A. Neves e A. M. Carvalho Neto (orgs.), Indústria Automotiva: A Nova Geografia do Setor Produtivo. Rio de Janeiro, DP\&A Editora.

ROCHA, Lia M. (2002), O Novo Discurso da Qualificação Profissional e os Trabalhadores do Consórcio Modular em Resende (RJ). Dissertação de Mestrado em Sociologia, Programa de Pós-Graduação em Sociologia e Antropologia. IFCS/UFRJ, Rio de Janeiro.

ROESE, Mauro. (2003), Problemas Globais, Respostas Locais: A Indústria de Móveis de Madeira no BR à Luz dos Enfoques de Cadeias Produtivas e Sistemas Regionais de Inovação. Tese de Doutorado. Unicamp, Campinas, SP.

SCOTT, Allen. (1999), “Revitalização Industrial nos Municípios do ABC, São Paulo Análise Diagnóstica e Recomendações Estratégicas para uma Nova Economia e um Novo Regionalismo". Relatório de Pesquisa, São Paulo, Agência de Desenvolvimento Econômico do $\mathrm{ABC} /$ Banco Interamericano de Desenvolvimento.

SENGENBERGER, W. e PIKE, F. (1999), “Distritos Industriais e Recuperação Econômica Local: Questões de Pesquisa e de Política", in G. Cocco, A. Urani e A. Galvão (orgs.), Empresários e Empregos nos Novos Territórios Produtivos: O Caso da Terceira Itália. Rio de Janeiro, DP\&A Editora. 


\begin{abstract}
New Industrial Configurations and Local Participation in Development Strategies

This article discusses patterns of institutional and political participation based on new economic development experiences in situations created by the dynamics of the Brazilian automobile industry in the 1990s. Taking an empirical study of a region as an example, the study argues that even in a context where large companies have opportunistic motivations (tax exemptions, low wages, etc.), initiatives can emerge for society's mobilization and intervention to foster collaborative activities aimed at regional development.
\end{abstract}

Key words: regional development; social networks; political participation; industry

\title{
RÉSUMÉ
}

Nouvelles Conjonctures Industrielles et Participation Locale dans des Stratégies de Développement

Dans ce texte, on discute des modèles de participation institutionnelle et politique à partir de nouvelles expériences de développement économique dans des situations créées par le dynamisme du secteur automobile brésilien dans les années 1990. Prenant comme exemple l'étude empirique d'une région, on postule que, même dans un contexte où de grandes entreprises sont poussées par des motivations opportunistes (dégrèvements fiscaux, bas salaires etc.), on peut trouver des initiatives de mobilisation et d'intervention de la société en général afin de stimuler des activités de collaboration visant le développement régional.

Mots-clé: développement régional; réseaux sociaux; participation politique; industrie 